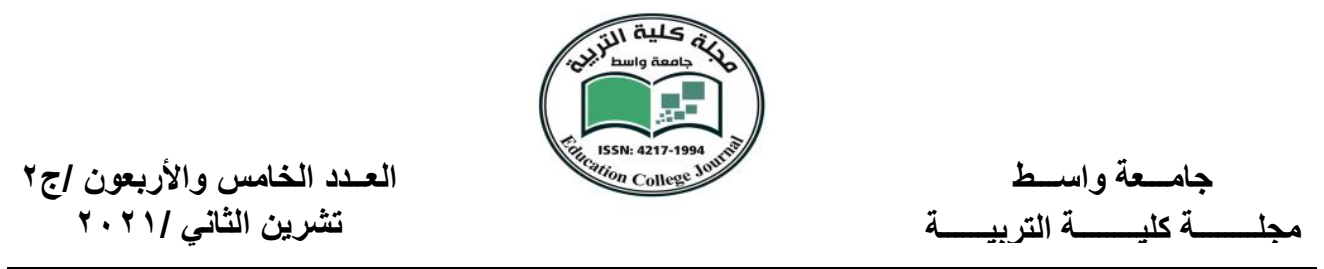

\title{
Identity and the theme of belonging in Seamus Heaney's Selected Poems
}

Assist. Lecturer. Shaymaa Saleem Yousif

Ministry of Education \Open Educational College 16ezlvi75j4b@mail.com

\section{Abstract}

The heritage and history of the ancestors and the country are important parts of the history and culture of peoples. It is the vessel which their faith, traditions, authentic values, language, ideas, and way of life derived from. It also shapes their personality by culture, national identity, and creates the bridge of communication between generations. The identity and the sense of belonging can be traced in the early poems of Seamus Heaney: Digging (1966), Gravities (1966), Traditions (1972) and Anahorish (1972). Many critics consider this as only self-revelation or as a result of feeling guilty for leaving his family, land, and career. This study aims at proving that in spite of the fact that Heaney had left his place of birth and his parent's tradition for choosing to be a writer, he presented poems that carry out the continuity of searching for the past and roots. The study concludes with that the sense of belonging has appeared through Heaneys early poems, reflecting his desire to plant the spirit of devotion to family, tradition, and Ireland.

Keywords: Seamus Heaney, Irish Poetry, Belonging, Traditions.

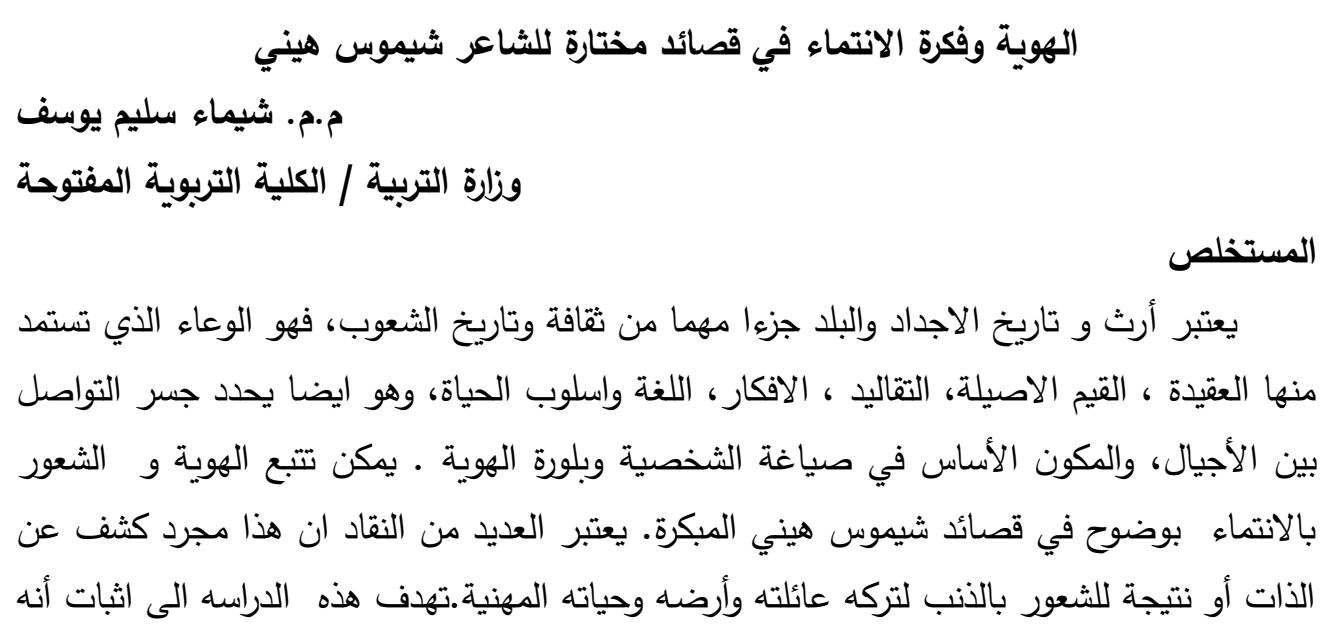




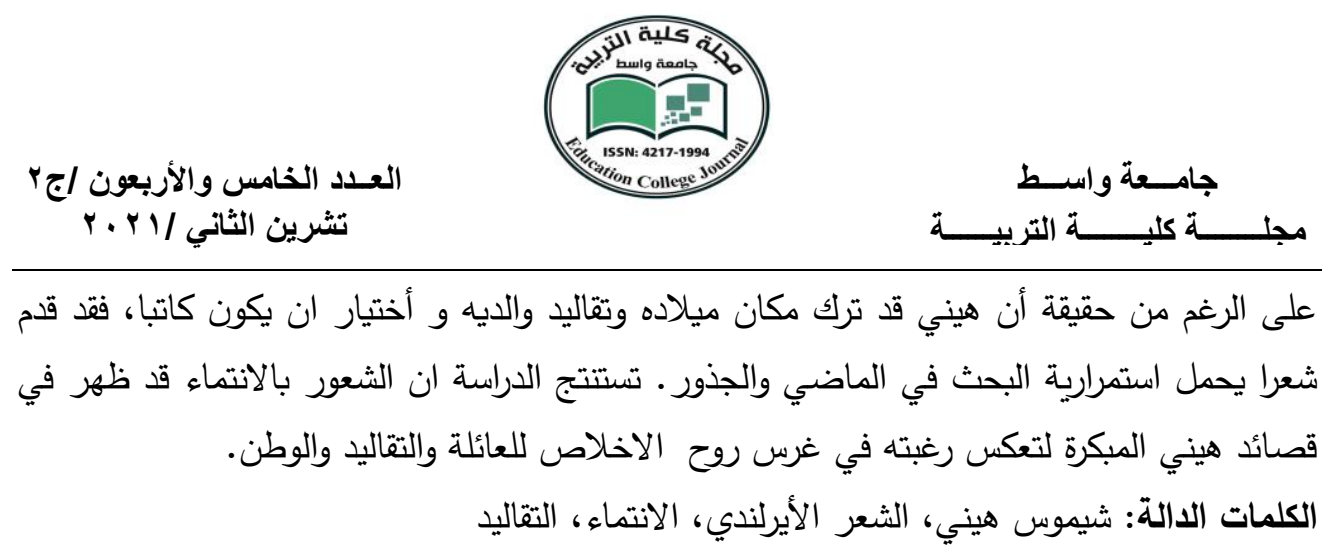

\section{Introduction}

Seamus Heaney (1939-2013) is an Irish contemporary poet, a translator, and a lecturer. He is regarded as one of the influential poets of the 20th century. He was born near Castle Dawson, in the north of Ireland, to a Catholic family and grew up on his father's cattle farm. Furthermore, he went to Anahorish Primary School near his home, when he was twelve years old; he won a scholarship to St. Columbia's College, a Roman Catholic boarding school (O'Brien, 28). Leaving his family and going abroad to seek an intellectual life, in an early stage of his life, explains to some degree his consisting telling about his lost childhood and his feeling of the sense of belonging to his family and land (Brandes, 102-3).

\section{Literature review}

The issues of identity and sense of belonging are consisted themes in Irish poetry since this country had been colonialized by British for centuries. Amal Riyadh states that Yeats was aware of the relationship between cultural identity and nationalism. She also asserts that Yeats was able to raise the national identity in Irish minds as he claims that nationalism and cultural identity are interwoven as the existence of one requires the existence of the other (487). Lucy Collins notices that Boland search for identity is a reflection of her search of herself as an excluded woman from political and cultural history of her nation (23).Collins adds that Boland uses her memories as she lived in different places as experiential foundation to inquire about the notion of belonging in terms pf personal and cultural relation to particular place (5). Michael Parker notes that Irish poetry can still base itself firmly upon what might be described as natural resources because in England very few poets indeed appeared to be interested with this kind of consciousness of nationality. This sense of belonging, however rebelliously, is connected to a 


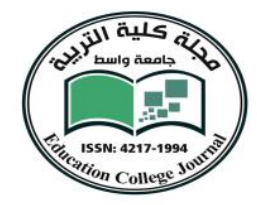

social or national group (36). Eugene O'Brien affirms that Heaney endeavored to tackle the theme of his relation to the land, history and culture to his people (31-33). He is not doing this aimlessly; he wants to motivate the young generation to have a strong relation to the homeland. In other words, it sprouts from Heaney's veneration and gratitude towards his ancestors. It is the values and principles of traditions that he wanted to instill in his nation conscience. His themes relate the companion of land, history and culture to revive the living past. Heaney intensifies a commitment to root his poetry in the Irish landscape. Through his poems, Heaney uses linguistic signs and place names to enhance a sense of community and to make a connection with the Irish past. It can be said that Heaney is a man and poet who felt the sense of belonging in many poems to reflect his originality and loyalty to his land, father and tradition. To illustrate this conception, the question of belonging overlaps with the questions of social cohesion.

A sense of belonging can be attainable from the connections made with people, places, communities and the larger world. Abraham Maslow, an American psychologist, states that the need to belong is a major source of human motivation and it is one of five human needs (physiological needs, safety needs, love and belonging needs, esteem needs, and selfactualization needs) (Suyono, and Sri, 30). These needs are organized on a hierarchy and must be orderly fulfilled. After physiological and safety needs are met, an individual can then work on meeting the need to belong and to be loved. The lack of this need results in loneliness, psychological distress (Ibid, 31). Then belongingness is the human sensitive need to be an accepted member of a family, friends, a religion, or something else. Therefore, people tend to have a desire to belong and to be part of something greater than them. This suggests a relationship that is bigger than simple association. According to Marshal Douglas "Belonging is alliterative shorthand for a larger idea, in this case one composed of attraction, identification, and cohesion. Just as belief is a step beyond knowledge, belonging is a step beyond membership " (360). Hence, without belonging, one cannot identify himself clearly because belonging is an important element that links individuals to institutions and community. Similarly, Heaney wants to be a part of something bigger and more important than himself, which is Ireland. Thus, when he writes these 
العـدد الخامس والأربعون اجr

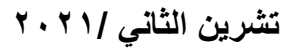

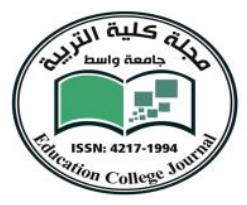

poems, he starts with the early periods of his life to pursue his relationship with his father, who is a symbolic character of the Irish man. This paper analyzes four poems from Heaney's two early collected poems.

In his landmark poem, Digging, from his first Poetry Collection, Death of a Naturalist (1966), Heaney deals with the themes of root consciousness and he respect to the ancestors. Some critics have suggested that this poem seemed to describe an actual moment of inspiration about Heaney's task to present a better image of his family and local's popular career. This poem reflects his connection strongly to his birthplace and his father, as he had a strong connection as a poet and as a child to the land (Padilla, 22). It also reflects his sense of belonging, as it is written "into one's psychic past, to explore one's past through archaeology, mythology, and etymology. It examines the natural longing for familial and continuity" (Bernard, 21).

The speaker uses simple elegant language, which made the poem easy to read not only by Irish but by foreigners too. The musical pattern of the poem with its beautiful denotation words make it easy to learn by heart even by non-native speakers. It is full of poetic images that describe Heaney's father career and his daily routine.

The poem opens with:

Between my finger and my thumb

The squat pen rests; snug as a gun.

Under my window, a clean rasping sound

When the spade sinks into gravelly ground:

My father, digging. I look down (Digging, L1-5, 7)

The use of simile is one of the great stylistic aspects of this poem. It is used twice, the first in the beginning, when the speaker is aware of the fact that his skill of digging with pen is a powerful as his fathers' act of digging with a spade. The pen for him and the shovel for his forefathers would be strong as a gun. They are tools of surviving and strength for both of them. In other words, his father's digging into the ground to bring potatoes, which is their source of living, is identified with the act of digging into the world to find the 


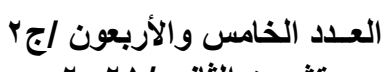

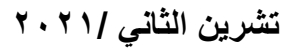

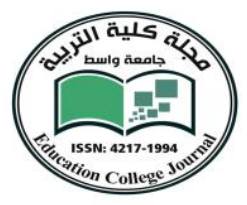

sense of intimacy, stability and belonging. The second use of simile is when the speaker emphasized his admiration for his father who handles a spade just like his old man:

Just like his old man.

My grandfather cut more turf in a day

Than any other man on Toner's bog. （Digging, L. 16-18, 7)

The father's image stands for the ancestry of modern Irish. As most of them are farmers, Heaney chooses this craft that is known for all Irish since Ireland is an agricultural country. Bernard O' Donoghue adds 'this poem results from the son's break both from the farming community, from the agrarian succession from father to son and from the father's own displacement from his role as cattle- dealer" (159). It is truly that Heaney had separated himself from his father and their career. However, He is going to have a different way that his interest is different; he is not a follower of the ancestors in the sense that he will have the same craft; he follows their responsibility, their feeling of belonging and their connection to the land.

In spite of the fact that he left his place of birth and his parents' tradition in choosing to be a writer and to live in the city, his poetry carries the continuity of spirit with his parents and a loyalty to his origins of place and race. Asserting this fact, Michael Parker writes, reporting Heaney: "I have two houses, this house and the house where I was brought up, when I go back, my father and mother are still alive, my brothers and sisters still around the place, I merge into it" (28). This statement reflects that a sense of belonging is consciously coming from his admiration towards his family and ancestry. This loyalty is another face of his loyalty to his nation. The memory of the father constantly visits his mind and will never go away. It is the source of his inspiration and creativity. The speaker mentions his grandfather positively to show the image of the strong family ties, which symbolically refers to the relations in society at large. Though the mode of digging is considered different from that of his ancestors, he is giving continuation to the tradition.

The closing stanza begins by repeating the first stanza: "Between my finger and my thumb/The squat pen rests." However, instead of making a 


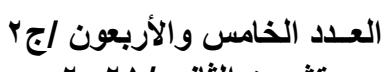

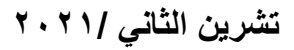

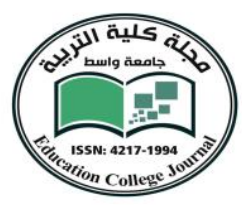

metaphor between the pen and a gun, this time he directly says, "I'll dig with it." This image simply reflects his intention to use his own tools, his pen, to dig. His idea is not that digging is significant when it is like writing, but that writing is significant when it is like digging. Both actions are blessed to him. Finally, the speaker affirms his desires to be like his ancestor very close to the land of Ireland, except that each one would live in different time and different circumstances. Through going on Heaney's life, one finds that he was perfectly able to use his poetic talents to keep his heritage.

In Gravities (1966), Heaney is insisted about the inevitable link between soil or landscape and the creative imagination in his mind about Ireland. Particularly, this theme has run throughout this short poem from the collection of Death of a Naturalist (1966). It is consisted of three stanzas, each one has four lines. However, this poem reflects many detailed and expressing images.

High-riding kites appear to range quite freely

Though reined by strings, strict and invisible.

The pigeon that deserts you suddenly

Is heading home, instinctively, faithful.

Lovers with barrages of hot insult

Often cut off their nose to spite their face,

Endure a hopeless day declare their guilt,

Re-enter the native port of their embrace. (Gravities, L.1-8)

The strings in the second line metaphorically represent the invisible link between soil or land and the creative imagination of the poet. Metaphorically, they symbolize the historical roots and the duties towards the ancestors. They are invisible, but they are there. These invisible strings also represent the unconscious force that attracts him back to his homeland. The speaker wants to tell us that going home when one needs to feel safety is the right choice because home matches the sense of belonging, a place of shelter, a place that he is familiar with warm memories, and he chooses it because it's a place that provides comfort, security, and protection. Therefore, he unconsciously and consciously goes home, which it would always welcome him if he returns. Symbolically, this home stands for the gravity of Ireland itself to its citizens. Tobin also confirms this saying "Gravity is the inevitable force that 


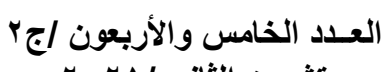

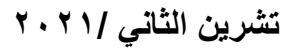

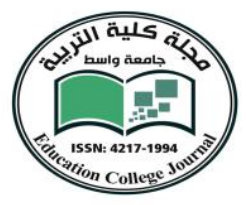

both limits us by determining the boundaries of identity and yet provides us with the essential milieu in which we struggle to exceed ourselves in relation" (26).The speaker perfectly presents the technique of personification, in the third line, when he talks about the pigeon that leaves its place and fly a distance, but suddenly has the feeling of wanting to return home. This allegorical reflects that there is a natural, unconscious force that pulls man back to his homeland. Daniel Tobin describes Heaney's endeavor to make "This poem moves through a series of juxtaposition relationship between freedom and limitation. Gravities offers the figure of James Joyce as a representation of the artist ruled by invisible string who despite his embrace of displacement in exile remains instinctively faithful in his works" (ibid).

The speaker also departs like the pigeon and the kite, but he always returns to his homeland. He continues:

Blinding in Paris, for his party-piece

Joyce named the shops along O'Connell Street

And on Iona Colmcille sought ease

By wearing Irish mould next to his feet. (Gravities, L.9-12)

Seamus Heaney has presented Irish places and landscape with distinct Irish characteristics like James Joyce who immigrated to Europe and lived in Paris, but he never forgets homeland and its culture. In the famous novel Ulysses, which sets in the streets and alleyways of Dublin, Joyce reasoned choosing this setting saying, "For myself, I always write about Dublin, because if I can get to the heart of Dublin I can get to the heart of all the cities of the world" (Bénéjam and Bishop,5). Heaney wants to remind the reader more about Joyce's true feelings towards his country, by saying that Joyce knows the streets of Ireland even if he is not living there. "O'Connell Street" and "Iona Colmslie" are Irish place-names stated to emphasize the link between the writer Joyce and Ireland (Yvonne, 136).

In the closing line of the poem, Heaney stresses his identity as an Irish speaker. This is how he is defending the Irish nation. He says that he and James Joyce would put Ireland in their minds even if they are in another country, and there is a strong connection that makes him always speak about Irish background. In addition to this poem, Andrews Elmer describes 


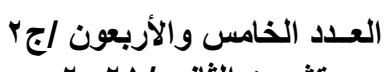

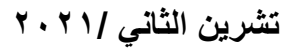

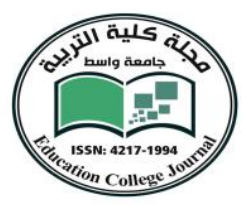

Heaney's craft trip as the one who begins investigating his childhood, then he gradually extends his searching of self to place it with relation to a communal past. He understands the present by bringing it into significant relationship with the past. (3)

Heaney wrote Tradition, which was written between 1969 and 1972, in his poetry collection Wintering Out, where many poems are taken from the backgrounds of Northern Ireland. As O'Brien confirms, "Heaney is writing very much from his own tradition" (2). In Northern Ireland, the birthplace of the poet, the English language was imposed on Irish people by vital institutions like government, churches and schools. This leads to the dominance of English language, which deprived the people from using their native language, the Celtic. Throughout his entire life, Heaney always felt deeply connected to Ireland's beauty, local folklore, and Irish tradition language. (Hickey, 37) Hence, searching for the roots of the past is one of the poet devices to glorify his nation. Heaney considers language as a medium or re-connection to culture origins, a medium of reassurance that helps the individual to anchor within community. Problematically, this process of anchoring may have become in a time of varied interest and opposing public narratives. (Ingo, 20) To revive the use of the native language and the history of his nation, Heaney found poetry the best and possible way to achieve this need. So he studied the history of his country and learned the Celtic language, the original language of Ireland. (Stefanović, 249)

This poem presents another classic example of Heaney's belonging, but this time for the past in general and for the original language of Ireland in particular, not only for the land. Donoghue states that this poem "begins with rueful, quizzical reflection on the forces that make an Irishman assimilate his speech to the decencies of the British Isles, which in effect gives privilege to the received standard English of London and the South of England" (9). So, the speaker outrages the use of English Language instead of the Irish. He opens the poem with referring to forgotten Irish words.

Vestigial, forgotten

Like the coccyx 


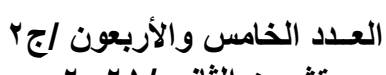

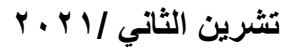

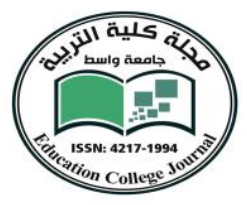

Or a Brigit's Ceoss

Yellowing in some outhouse" (L.5-8,).

According to Collins English Dictionary, the word "coccyx", is a Greek word which means tailbone, the final segment of the vertebral column in all apes, and analogous structures in certain other mammals. People in Ireland used to gather these small bones to build nest and placed them near their doors as an old tradition here, it symbolizes the source of the Irish language. Also, the "Brigit's cross", which is a small cross usually woven from footages it has become one of the symbols of Irelands slogans. The crosses are traditionally made in Ireland on St Brigit's feast day, marking the beginning of spring. Besides, the Celtic cross means a personal expression of faith, or it refers to Irish tradition. The Celtic Crosses can be found wherever one finds people of Irish descent (O'Duinn, 121). The Celts culture and Celtics language, is one way of uniting the Irish because they all belong to that category, they have similar background and history. Therefore what bonds them is their past because they cannot isolate themselves from it. Returning to the past is an important element to them.

In the second stanza, "between ban and moss land", the speaker uses a puzzle-words in dividing the word "mossland" to moss and land, then replacing the word "land" by the word "bawn", the result will be "Mossbawn" the birthplace of the poet.in the rarly stage of his career, Heaney has written about different experience he has where he has placed his poetic ear to his homeland" (Christie, 38). By using these personal references, He is invites the readers to share his outrages feelings and anger, because of the language situation of Irish. He ends up his poem, with answering the rhetorical question: "What is my nation?" (L-10) .To emphasize his purpose of writing this poem, this is to revive the language and the existence of his country, and to insure his identity as an Irish.

And sensibly, though so much

later, the wandering Bloom

replied, "Ireland," said Bloom,

"I was born here. Ireland. (Tradition, L.34-7,)

These lines are reference to one of the earliest stages of the existence of Irish; it is used to refer to , MacMorris from Henry $V$ (1599) by William 


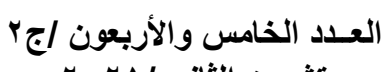

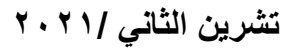

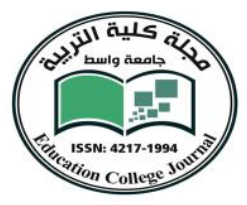

Shakespeare, and to Leopold Bloom, the protagonist in Joyce's Ulysses (1922) (Matters, 55). Bernard Donoghue also comments on the purpose behind the use of such reference is that Heaney's poems in North especially, show that he has accepted particular responsibilities as a poet of the Northern. In other words, "he has evidently felt uneasy not about his feelings but about their not being the right ones, adequate to their occasion" (11). By repeating the word 'Ireland' twice, the speaker highlights his nationality and declares his identity. Consequently, the subject of being Irish is the main theme in this poem.

In Anahorish (1972), the sense of belonging is presented theme in many of Heaneys poems. It gives a foundation upon building this poem, Anahorish, the fourth poem in his third collection Wintering Out. Its tittle is taken from' Anach fhior usice ', the place of clear water (Berensmeyer, 68) and it is the name of Heaney's local primary school ( Brandes, 102). Besides, it is an important historical place for the heroic deeds that took place there. Michael Parker regards that this poem, "Anahorish", is a temptation to re-connect "the energies of generation coursing through man, land and language...to restore continuity while acknowledging change" (98). Heaney represents a man who is laboring to find a sense of home or belong in both rural and urban locals in the past and present. Sidney Burris states that in Anahorish: "Heaney imagines that the name itself possesses ineffable powers of cultural sovereignty" (12). Heaney explains that this kind of poem is usually written to bring to the present a type of old Irish poetry named "dinnseanchas" which refers to the origins of place-names and traditions concerning events and characters that is related with the places (Yaorong, 8).

This trace of origin name is very important for the poet, because when he traces a place name he could feel the sense of continuous tradition through bring the past and build a culture on it. This is emphasized by Tim Robinson as he claims "Place-names are the interlock of landscape and language". (155) Heaney has different memories for different districts. The scenery in Ireland is beautiful, so he admired the land for its beauty. This sense of Placenames helps Heaney to emphasize belonging. He opens the poem describing the beautiful land, saying:

My "place of clear water," 


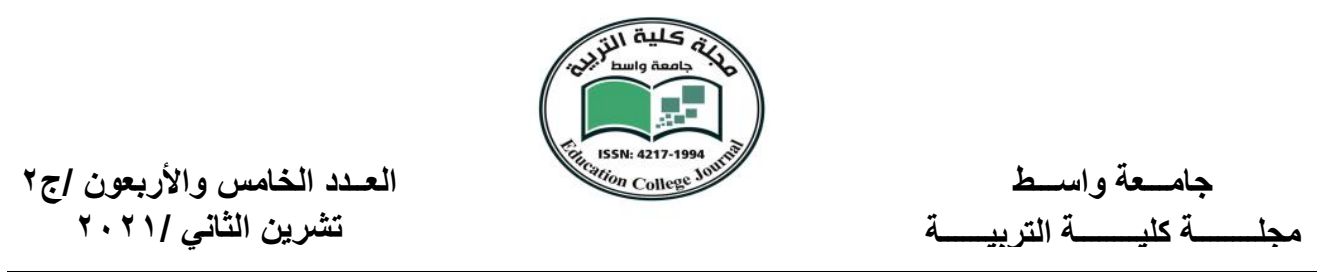

the first hill in the world

where springs washed into

the shiny grass. (Anahorish, L.1-4,)

The first scene reveals Heaney's growing commitment to root his poetry in the Irish landscape. The poet uses linguistic signs and place names to develop a sense of community with the Irish past. Heaney recalls that history and its legacy as well as any Irish writer ever has. There is no hint of romantic Ireland in any of these poems, yet the love for Ireland is there, a love of Ireland as it really is and has been. (Moran, 16) This poem is rich with allusions to Irish places, and it is acknowledging of Heaney own origins. $\mathrm{He}$ creates a bridge between what he always belongs' home', families, craft, and the present discontinuity which he lives now in 'exile'. "The exile of the poet is symbolical and always represents, paradoxically, a' homecoming', because the journey he undertakes is one whereby he comes into his own ground, where he reaches 'the first circle' of himself." (O' Donoghue, 29) Then, the poet wrote this poem to evoke the sense of happiness of his childhood. $\mathrm{He}$ closes his lyrical poem by indicating to his feelings toward these places saying that: Those mound-dwellers /go waist-deep in mist (L.13-14)

Heaney uses the land as a representation of what he reminisces from the landmarks to inspire his memories of his old primary school. The lines: To break the light ice / at wells and dunghills (Anahorish, L.15-16) signifies his desire to investigate deeply into his past, so he can have a sense of future as well as. In fact, the land, in this poem, represents many things, but always summarizes continuity of experience. Whether the speaker is searching for personal meaning or trying to trace a source and possible context for the troubles in Ireland, he finds his language and inspiration firmly rooted in the land, as if he wanted to speak for others.

Generally, the idea of bringing some places or some modes of life, in the Irish poetry has become an Irish obsession, because this is their way of defining themselves and protecting their identity. In general, the Irish poetry is a literature that concentrates on the local points and the common language of the Irish people. Symbolically, the background or the common elements in these four poems are heritage (tradition), land (locals), and language and 


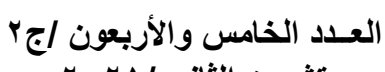

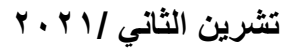

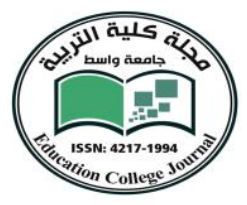

roots. They are the source of different images. They are used to emphasize the sense of belonging and the identity of Heaney as an Irish poet.

In conclusion, Seamus Heaney is a poet whose poems arouse a sense of belonging. These early poems depict the life of rural laborers digging, turfcutting, purging unwanted animals, and their other tasks and observations of natural phenomena. He always revisits motifs from his earlier Collective Poems in the later texts. The sense of belonging is a present element in many of his poems. It builds a foundation upon which to form his poetry. Talking about the career of his ancestry, bringing the names of places mentioning the Irish poets like Joyce, and talking about land. All these tasks helped him to bridge the gap between the past and present to inherit the tradition and culture of ancient Ireland. Placing himself between the domestic and exterior world and between the present and the past enables Heaney to project his future as an artist. Therefore, he writes to show his talents in using the meaning and sounds, literature techniques, intellectual use of stories or themes and so on. Furthermore, Heaney uses his poetic talent to express his feelings and to motivate his citizens to share with him these senses.

Seamus was blamed of being an escapist that he ran out from reality to his farm, memories, and his past. The reply to this accusation is that his task is to present a new image of the Irish. The Irish image was still deformed and vague, so he was remaking a new image. His second task is to defend his identity as an Irish poet. The research concludes that Heaney wanted to reflect or employ his personal sense of belonging and turned it to serve a general purpose. To conclude, Heaney does not separate himself from his family, root, and land. Heaney's sense of belonging springs from his admiration and gratitude towards his ancestry. This sense also comes from the poet's desire to motivate the young generation to make a strong relation to the homeland.

\section{References}

Andrews, Elmer. Poetry of Seamus Heaney: All the Realms of Whisper. Springer, The Macmillan press, 1999. 

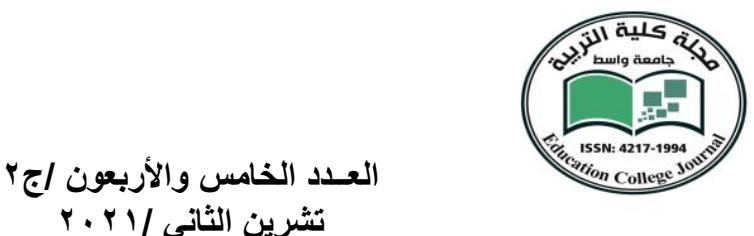

Bénéjam, Valérie, and John Bishop, eds. Making space in the works of James Joyce. Vol. 19. Routledge, 2011.

Berensmeyer, Ingo. "Identity or Hybridization? Mapping Irish Culture in Seamus Heaney and Paul Muldoon." Études irlandaises 28.1 (2003): 65-83.

Brandes, Rand, "Seamus Heaney." Modern Irish Writers: A Bio-critical Sourcebook. Greenwood press, London:1997.

Burris, Sidney. The Poetry of Resistance: Seamus Heaney and the Pastoral Tradition. Ohio University Press, 1990.

Christie, Tara. "Something to Write Home about": Seamus Heaney at the Hardy Birthplace." The Thomas Hardy Journal 20.2 (2004): 35-45.Collin,

Collins, Floyd. Seamus Heaney: The Crisis of Identity. University of Delaware Press, 2003.

Collins, Lucy. Contemporary Irish Women Poets: Memory and Estrangement. Liverpool University Press, 2015.

Donoghue, Denis. "We Irish: Essays on Irish Literature and Society: Berkeley." (1986).

Duinn, Seán Ó. The Rites of Brigid: Goddess and Saint. Columba Press, 2005.

Hall, J., and A. Crowder, eds. Seamus Heaney: poet, critic, translator. Springer, 2007.

He, Yaorong. "Language and Landscape-Dinnshenchas in Seamus Heaney's Poetry." Advances in Literary Study 4.01 (2016): 8.

Heaney, Seamus, New Selected Poems 1966-1987. London: Limited Faber and Faber, 1990.

Hickey, Ian. "Virgilian hauntings in the later poetry of Seamus Heaney." 13, (2018).27-40

Hoffmann, Charlotte, ed. Language, culture and communication in contemporary Europe. Multilingual matters, 1996.

Kitishat, Amal Riyadh. "William Butler Yeats: The Hidden Nationalism." Journal of Language Teaching and Research 10.3 (2019): 484-489.

Marshall, Douglas A, Behavior, belonging, and belief: A theory of ritual practice Sociological Theory 20.3 (2002): 360-380.

Moran, Seán Farrell. "Remembering Seamus Heany: Poetry and the Historians." Oakland Journal Number 25: Winter 2015 (2015).5-21

O'Donoghue, Bernard, ed. The Cambridge Companion to Seamus Heaney. Cambridge University Press, 2009.

O'Brien, Eugene. "Seamus Heaney: Creating Irelands of the Mind Studies on Contemporary Ireland Series." (2007).

Padilla, Juan Ráez. "Seamus Heaney’s elemental ecopoetics: Earth, water, air and fire." Journal of Ecocriticism 1.2 (2009): 21-30.

Parker, Michael. Seamus Heaney: the making of the poet. University of Iowa Press, 1993.

Heaney, Seamus, and James Randall. "James Randall: From the Archive: An Interview with Seamus Heaney." Ploughshares 37.1 (2011): 173-188.

Robinson, Tim. Setting foot on the shores of Connemara and other writings. Dublin: Lilliput Press, 1996. 


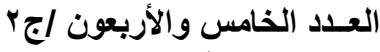

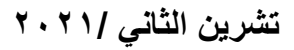

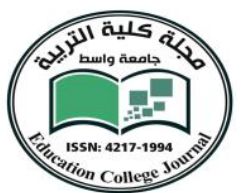

tion College 3

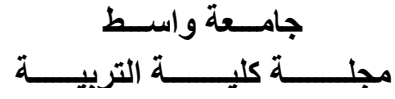

Stefanović, Suzana, Seamus Heaney-the poet and his tradition, Fact University -Linguistics and Literature 2.08 (2001): 243-256.

Tobin, Daniel. Passage to the Center: Imagination and the Sacred in the Poetry of Seamus Heaney. University Press of Kentucky, 2014

Whelan, Yvonne. "Symbolizing the state - the iconography of O'Connell Street and environs after independence (1922)." Irish Geography 34.2 (2001): 135-156. 